\title{
The Deteriorating Register on Papalele Women Profession
}

\author{
Romilda Arivina da Costa $^{1 *}$, Falantino Eryk Latupapua ${ }^{2}$ \\ ${ }^{1,2}$ Pattimura University \\ *Corresponding author, email: ronaromilda70@gmail.com
}

\begin{abstract}
Papalele is a tradition where adult women of Ambon's mountainous areas would sell crops. Nowadays, the number of papalele women that go around selling crops is decreased. This affects the deteriorating register in Ambonese Malay language (AML) concerning their profession. Based on that background, a qualitative study was conducted on papalele women from mountainous areas, i.e. the villages Ema, Kilang, Hutumuri, and Hatalai. The data was collected using the open interview method, then analyzed descriptively and introspectively. The study results show that the deteriorated register occurs in the form of specific words and phrases; with politerm-monoterm pattern; (ii) symmetrical substitution pattern. The cause of the decreasing number of papalele women in the intensity of papalele activity is the effort to increase the family's social status, thus the inheritance efforts of this tradition to the younger generation are close to never. The papalele women themselves have, indirectly, contributed to the deteriorating register of their profession.
\end{abstract}

\section{Keywords: papalele women, deteriorating register, Ambonese Malay language}

\section{FOREWORDS}

Papalele is a term in Ambonese Malay language (AML) describing the activity of selling crops in Ambon city centre, generally done by women from the island, specifically from villages in Leitimur Selatan area. By the people of Ambon, that area is colloquially known as the mountainous area or simply the mountain. Those coming from that area are called mountain people.

This study will restrict the meaning of papalele tradition to the scope of selling done by adult women from the Leitimur Selatan area, or the mountains, as a suburban tradition that contributes to the uniqueness of the people in Ambonese mountains. This will limit the study since many other areas in Ambon municipality have papalele traditions. However, the papalele from the mountains is the most significant and most known as the icon for traditional economic activity. It is a tradition that directly engages women and the community's daily life, which, unfortunately, experiences deterioration.

One of the indicators of the apparent deterioration is the decrease in the number of papalele women from the five villages, caused by various factors. This occurrence linguistically affects the register deterioration or shift in AML concerning their profession or work [1].

Thus far, the study or discussion on papalele women's profession uses several perspectives, such as economy, philosophy, contextual theology, and sociology. Although, the profession is untouched sociolinguistically. Speaking of papalele as part of tradition or culture must not neglect the role of language as means of communication and as an identity of the group or community. This study, therefore, aims to describe sociolinguistically the deterioration of register or language variation used by groups of papalele women from villages of Ema, Kilang, Hutumuri, and Hatalai along with its various affecting factors.

\section{THE CONCEPT OF PAPALELE}

Papalele consists of two words, papa meaning 'to carry' or 'to shoulder,' and lele, meaning 'around.' Therefore, papalele means 'to carry around" or "to shoulder around." Papalele exists in traditional economic activities, especially in trading, of buying crops and selling them back to gain little profit [2]. This concept only applies to 
those indigenous to this area, not settlers. Therefore, the settlers in trading businesses are known as tradespeople [3].

Papalele, as defined by Soegijono [1], is a form of economic activity focusing on a buy-sell pattern with actors mainly consisting of women. Papalele is considered unique because of the attire worn, such as costumes and accessories to support selling. This identity affirms that papalele is a local trader, different from other kinds of traders.

The items being papalele varies in accordance to several aspects, such as (i) the current season; (ii) location of residence and communal pattern; (iv) how accessible it is to attain materials or ingredients [2]. Accessories commonly used by papalele women are dulang (tray, container), basket, flat tray from woven bamboo, loyang (pan), and leaves. Besides those, the typical dress worn by papalele women is usually accessorized with cole (Ambonese camisole) and white cloth as tying tools. The clothing's neckline or collar, cuffs, and bottom part of the shirt are also accessorized with laces, thus making them look simple but presentable [2].

\section{THE CONCEPT OF REGISTER AND DETERIORATION OR SHIFT OF LANGUAGE}

The register is one of the complicated factors in any discussion of language varieties. The register itself is a set of vocabularies associated with different occupational or social groups. The existence of traits that differentiates a person coming from a specific place, group, or profession is interesting as these variations will provide knowledge about new or different concepts [4].

Deterioration of language or shift of language means a community or group of people abandon their language and use another instead, whose progress is often not realized by the speakers. The factors causing deterioration of language, as written by Summer Institute of Linguistics [6], among others (i) the small number of its speakers; (ii) age of speakers; (iii) whether children are using it; (iv) feeling of identity and attitude towards the language in general; (v) urbanization of younger generation; (vi) use of language in education.

\section{METHODS}

The data was collected through interviews utilizing note-taking and voice recording techniques. The interviews during data collection were done informally with every papalele woman as a source of information, talking about their daily lives, including papalele activities that these women do in villages of Ema, Kilang, Hutumuri, and Hatalai, located in the Leitimur Selatan subdistrict.
Voice recordings from the interviews were then transcripted orthographically. After synchronizing the data from voice recordings and written notes, the data was processed and classified. The method to analyze data was descriptive and introspective method. Descriptively, the analysis was done by explaining the relations between the collected data with the meaning surfacing among subjects of study concerning papalele activities performed. Introspectively, the data were compared to describe vocabularies used, which decrease in their usage, then vanish (hardly ever used or heard) or only being kept in the memories of papalele women and their peer speakers.

\section{ANALYSIS}

Leitimur Selatan is the name of a subdistrict in the Southern Ambon island, it is the result of the expansion from Sirimau subdistrict - the most populated subdistrict on the island [5]. The communities' daily lives in the mountains are relatively simple. The general livelihoods are farming perennial crops such as durian, cloves, nutmegs, and other fruits. Traditionally farmed crops, mainly fruits, are well-known in Ambon City. In villages located on the shorelines (such as Naku, Kilang, and Hukurila), the people usually have two professions, traditional fishers and farmers growing annual or perennial plants.

With such scale of geography, demography, and social-cultural situation, papalele as means of traditional trading activity has been implemented since the Duch colonial era. Papalele became a vital tradition in understanding the development of people in Leitimur Selatan as women took the role in this tradition and increased the economy by trading.

\subsection{Papalele Women Through The Ages}

Souissa [2] explains that the presence of papalele women is closely related to the historical context of the people in Ambon island. The Hongi policy (monopoly of trades) under the devide et impera politics debilitated the economic strength of the people during the VOC era. The men were driven to slavery in clove farms, so the women took an essential role in domestic matters, including daily livelihoods.

Nowadays, AML speakers generally use the term bajual (selling) instead of papalele to identify the economic activities of trading or selling. Although the term papalele that refers to specific subject tanta-tanta papalele (adult women who are doing papalele) are still being used, they are no longer identifying the trading activities, but more to affirm the identity of a subject, which is the women from the mountains of Ambon City who are trading crops. These women usually take the crops to the city using bamboo baskets called atiting or 
tagalaya that they put on top of their heads. Most of the women started this profession when they entered marriage, thinking that they could support the family's economy. They mostly do not inherit this profession from parents, but more on selfinitiative after seeing the success of their peers.

\subsection{Papalele Women: The Last Surviving Generation}

The characteristics of papalele women from the mountains of Ambon city are easily recognizable. They would wear white or pink kebaya (traditional blouse) combined with a plaid sarong. Their hair would be rolled up, forming a traditional hair bun behind their heads. Their dialects are unique, different from those spoken by the Ambonese who live downtown. Concerning their papalele activity, these women from the mountains usually walk around on foot while carrying tagalaya on their heads.

The papalele women who are still doing trading activities today are all above 60 years of age. Younger women from the mountains who have tasted "modernization" no longer see papalele as a choice of profession. This is caused by their high education level, therefore creating different orientations for a profession. Among younger women of the mountains, there is an adage saying if our parents already carry tagalaya (tray) on their heads, we should not do the same. The adage means that the children must have better jobs compared to their parents, whereas papalele is considered a lower stratum and is positioned below many other occupations, such as civil servants or shop owners. It is for that reason that papalele women do not want their children to follow in their footsteps.

The effect of modernization that could be seen since the 1980s is the change in choice of fashion. In the beginning, cloth and kebaya (traditional blouse) were compulsory, not only for the villages in Ambon city, but almost for all villages in Maluku. The change of preferences from kebaya to kalet (local term for non-kebaya. The mountain people recognize this term as an antonym or the opposite of kebaya). This phenomenon occurred gradually when the newer generation of mountain people started to 'mingle' with modernity through education, circles of friends, and mixed marriages. The change of appearance does not only happen to choices of clothing. The method of rolling the hair bun, as explained before, is also being gradually abandoned, changed to a more modern hairstyle (without buns). Besides the way they dress, other accessories supporting the activity of papalele are also slowly changing. Atiting and tagalaya are replaced with baskets or other containers made from plastic.
The phenomena of change in choices of profession and circles of friends, education, and mixed marriages began to occur when the mountainous areas were no longer isolated as roads and electricity were introduced from the end of the 1980 s to the early 1990 s. When newer generations experienced higher education and a wider circle of friendship, their views on cultures, economic orientation, and professional choices also changed. The younger generation of men and women, those pursuing to study, would choose to migrate and continue their education downtown. On the other hand, the phenomenon only creates a vortex of economic, social, and cultural alienation to the older generation, including papalele women.

\subsection{Register of Papalele Woman And Its Deterioration}

The interviews with professionals of papalele ron (to affirm the characteristics of the activities, papalele ron is being distinguished from papalele $d u d u$ or papalele tanding) from villages of Ema, Kilang, Hutumuri, and Hatalai, resulted in several lexicon. The following is the classification for papalele women register.

(a) Lexicon on clothing ger $=$ collar on a kebaya (traditional blouse)

tali kaeng $=$ a cord made from white cloth, wrapped on the body as belt on sarong.

cole $=$ underclothing usually worn under kebaya

(b) Lexicon on accessories

tagalaya $=$ an oval container, woven a little deep

pinbil $=\mathrm{a}$ woven container with needlepoint holes

eceng $=$ a container made from sliced bamboo

mata langsa $=$ a woven container with holes a little larger than pinbil

atiting $=\mathrm{a}$ container used to collect cloves during havest

pundi-pundi tali kaeng $=$ a wallet to keep money, sewn specifically on tali kaeng

monelang $=$ a pocket to keep money

dulang $=$ a round wooden tray with flat surface

loyang $=$ a place to put goods to be sold

(c) Lexicon on the activities

tandeng $=$ to measure; sit still manyaga $=$ to make a promise/contract; to make a deal

(d) Lexicon on the goods being sold lecing atau lacing = lychee fruit manggustang $=$ mangosteen 
nangka blanda $=$ soursop

(e) Lexicon on the profits from papalele and its measurements

kepeng gareja $=$ money set aside to give as offering to the church sabunti = not much, but not too little; sufficient

(f) Lexicon on position and place tangada $=$ facing ewang $=$ forest

(g) Lexicon on time and seasons markings

poka-poka $=$ early in the morning; dawn

oferfron $=$ the beginning of durian season

Referring to the discussion on papalele women through the ages and the list of register classification above, it is quite visible that the life and activities of papalele women give a considerable contribution to the AML vocabulary. The study results show that register or language varieties in terms of lexicons or phrases that may be used in papalele by women from the four villages are experiencing significant deterioration. Some registers are now unknown since they have no equivalent meaning in the Indonesian language (BI).

\subsection{Register of Papalele Woman And Its Deterioration}

The deterioration of vocabulary in AML is manifested in two patterns, (i) politerm-monoterm pattern; (ii) symmetric substitution pattern. The prior has close relevancy to one of the semantic relations called hyponymy-hypernymy. This politerm-monoterm pattern is indicated through the specification of several lexicons which has been used before with their characteristics and turn it into only one terminology (may also be with its synonym), which is more commonly used and known this time. In turn, the second pattern is more relevant with the synonym aspect that is a semantic relation that affirms the similarity of meaning between one word or phrase with another (singular and plural).

The result of the study shows that two groups of lexicons are included in politerm-monoterm: bakol and dompet classified under lexicons on accessories, also the term konde which falls under the lexiconss on clothing and accessories. The variety or cohyponym bakol which previously known or used as its function is tagalaya, pinbil, eceng, mata langsa, and atiting, is no longer being used as it has been simplified to hypernim bakol. Although, the terim bakol experiences symetric substitution to become basket. This happens because papalele women rarely use bakol anymore, and turn to using keranjang, loyang, nyiru. Therefore, the group bakol is said to experience double deterioration in time, which is the politermmonoterm pattern, and continues with symmetric substitution pattern.

The variety or cohyponym dompet which was known or used before as its function of pundi-pundi tali kaeng and monelang, is no longer being used as it has been simplified to hypernym dompet or tas. This also happens to camara and ekor bebe as varieties or cohyponym with different forms, now no longer being used as they have been simplified to hypernym konde. Besides that, the terms that have been deteriorated tend to be substituted to other terms that show similarities in meaning or relations in definition, whether they are singular or phrasal terms. The groups of lexicons whose deterioration follows the pattern of symmetric substitution themselves may be substituted one by one and plural or more than one. The plural substitution may happen gradually or all at once.

The groups of lexicons whose deterioration happen in singular substitution may be seen in words such as:

(a) Deterioration of terms related to clothing and accessories

ger $\rightarrow$ krak $\rightarrow$ collar

tali kaeng $\rightarrow$ belt

cole $\rightarrow$ brassiere $\rightarrow$ singlet

(b) Goods sold

lecing or lacing $\rightarrow$ lychee

manggustang $\rightarrow$ mangosteen

nangka blanda $\rightarrow$ soursop

(c) activities

tandeng $\rightarrow$ to measure; sit still

manyaga $\rightarrow$ to make a promise

(d) position and place

tangada $\rightarrow$ facing; face to face ewang $\rightarrow$ forest

Meanwhile, the groups of lexicons whose deterioration happen in more than one substitution are visible on words relating to (e) the profit from papalele and its measurement; (f) time and season marking. The substitution form on these two groups may happen gradually, or all at once. The deterioration of the terms kepeng gareja and sabunti is classified as gradual substitution, and the deterioration of the terms poka-poka and operfron happens gradually, then all at once. The following will show the mentioned substitution pattern.

Papalele women define the profit from papalele that they set aside to give as offerings to the church as kepeng gareja. The women will put the offering into offering pouches, called tanggu, distributed during church fellowship. Therefore, the term 
kepeng gareja is then mixed-up with uang tanggu (money for tanggu). The term kolekte or 'collecting offering money' is widely used in the next development, so the terms kepeng gareja and uang tanggu are rarely used. Today, it is called persembahan (offering), following the most common term.

The term sabunti to define the profit from papalele was motivated by the feeling of sufficiency of profit from sales, thus the term has a meaning of 'not much, but also not so little.' Nowadays, the terim sabunti is seldom used as it has been replaced with a more common word, lumayan, meaning 'not bad.'

Because papalele women must race with time and distance to walk, from the mountains to downtown, the term poka-poka, 'very early in the morning,' was always used. Meaning that they must not be late. The expression then experienced a shift as people replaced it with the phrase amper siang, 'dawn,' as AML speakers commonly use it. Later on, the two phrases were then replaced with pagi-pagi sekali (very early in the morning) as an effect of the Indonesian language that is used in schools in the mountains.

Ambonese always wait eagerly for durian season, and the taste of durian from the mountains is extraordinary. Therefore, the signs of the coming of durian season are closely examined and gain its name oferfron or tanda di muka (signs ahead). Although the effect of strong modern AML along with influence Indonesian language on the younger generation replaced the term to AML phrase maso musing duriang (entering the durian season), or in BI awal musim durian (the beginning of durian season).

\subsection{The Cause of Register Deterioration}

Seeing the underlying causes from the traditional teritorial description of papalele women, along with its existence and classification of lexicons concerning papalele activities, we can explain that the register deterioration on papalele women profession tend to be caused by the changes in ecosystem (physical and social environments), such as road accessibility, good transport system, also the changes of use in tools and raw materials.

Besides that, the increase of social status of a family caused papalele women to direct the younger generation in the family to gain higher education so that they would not need to continue the profession, which decreased the number of papalele women. Logically, the lessening number of speakers affected the use of register, since peer speakers who understand them also reduced in number.

\section{SUMMARY}

From the study and result of data analysis, we can summarize that the lessening of the papalele profession is caused by several issues, (1) the changes in professional preferences; (2) the improvement of economy and education among younger generations; and (3) interracial marriages. Meanwhile, an important finding concerning papalele women concerning register deterioration are: (1) to improve the family's social status, papalele women profession is seldom being passed down to the younger generation in the family; (2) the papalele women indirectly took away the chance for their children to recognize the register of their profession; (3) the papalele women contribute positively to the register deterioration of their profession, besides the changing ecosystem; (4) the deteriorated register is in the form of specific words and phrases.

\section{AUTHORS CONTRIBUTION}

Both authors conducted the research and write this article in their speciality of research field and perspective. Romilda Arivina da Costa is a linguist; giving a theoretical framework in sociolinguistic for this research. Falantino Eryk Latupapua has interested in literature and oral tradition, as well as cultural studies, so he has attached cultural perspectives in data analysis.

\section{ACKNOWLEDGMENTS}

We appreciate much support from Pusat Studi Bahasa, Pattimura University, especially to Miss Maria Martha Nikijuluw and staff for all favours. We also acknowledge Mrs Suzana (Sanny) de Queldjoe-Hehareuw, Mama Ake (Mama Nyonya) Rihulay, and Oma Rachel Latuheru from Kilang; Oma Anto Palapessy and Oma Poppy Diaz from Ema, also Oma Batje Muskitta from Hutumuri, Oma Onna Kastanya and Oma Poppy Waas from Hatalai, with their genuine knowledge and experiences which were conducted this research to its existence.

\section{REFERENCES}

[1] Soegijono, S. P. (Ed.). (2016). Kolaborasi Papalele sebagai Kekuatan Ekonomi Lokal. Ambon: UKIM Press.

[2] Souissa, Nancy. (1999). "Papalele: Ajang Hidup Berteologi Perempuan Ambon". Thesis of a Religious Sociology Magister, Satya Wacana Christian University, Salatiga.

[3] Koritelu, Paulus. (2000). "Studi tentang Budaya Papalele di Desa Pelauw, Kecamatan Pulau Haruku, Kabupaten Dati II Maluku Tengah". Study Report in The Faculty of Social and Political Sciences, Pattimura University, Ambon. 
[4] Wardaugh, Ronald. (2002). An Introduction to Sociolinguistics. Fourth Edition. Oxford: Blackwell Publishers

[5] BPS Provinsi Maluku. (2019). Leitimur Selatan dalam Angka 2019. Ambon.

[6] Ibrahim, Gufran A. (2011). "Bahasa Terancam Punah: Fakta, Sebab-Musabab, Gejala, dan Strategi Perawatannya" dalam Jurnal MLI No. 1, Tahun ke-29. 